\title{
TEMPORAL AND SPATIAL VARIABILITY IN THALWEG PROFILES OF A GRAVEL-BED RIVER
}

\author{
MARY ANN MADEJ* \\ US Geological Survey Western Ecological Research Center, 1125 16th Street, Room 207, Arcata, California 95521, USA
}

Received 30 October 1997; Revised 9 December 1998; Accepted 29 March 1999

\begin{abstract}
This study used successive longitudinal thalweg profiles in gravel-bed rivers to monitor changes in bed topography following floods and associated large sediment inputs. Variations in channel bed elevations, distributions of residual water depths, percentage of channel length occupied by riffles, and a spatial autocorrelation coefficient (Moran's $I$ ) were used to quantify changes in morphological diversity and spatial structure in Redwood Creek basin, northwestern California. Bed topography in Redwood Creek and its major tributaries consists primarily of a series of pools and riffles. The size, frequency and spatial distribution of the pools and riffles have changed significantly during the past 20 years. Following large floods and high sediment input in Redwood Creek and its tributaries in 1975, variation in channel bed elevations was low and the percentage of the channel length occupied by riffles was high. Over the next 20 years, variation in bed elevations increased while the length of channel occupied by riffles decreased. An index [(standard deviation of residual water depth/bankfull depth) $\times 100$ ] was developed to compare variations in bed elevation over a range of stream sizes, with a higher index being indicative of greater morphological diversity. Spatial autocorrelation in the bed elevation data was apparent at both fine and coarse scales in many of the thalweg profiles and the observed spatial pattern of bed elevations was found to be related to the dominant channel material and the time since disturbance. River reaches in which forced pools dominated, and in which large woody debris and bed particles could not be easily mobilized, exhibited a random distribution of bed elevations. In contrast, in reaches where alternate bars dominated, and both wood and gravel were readily transported, regularly spaced bed topography developed at a spacing that increased with time since disturbance. This pattern of regularly spaced bed features was reversed following a 12-year flood when bed elevations became more randomly arranged. Copyright (C) 1999 John Wiley \& Sons, Ltd.
\end{abstract}

KEY WORDS: gravel-bed river; longitudinal profiles; pool-riffle morphology; Redwood Creek; residual water depth; spatial autocorrelation; thalweg

\section{INTRODUCTION}

Flow resistance in gravel-bed streams is influenced by the particle size present on the channel bed surface (skin friction) and form roughness caused by bed irregularities such as bed forms and pebble clusters. However, deformation of the velocity field associated with larger-scale features of bed topography, flow obstructions, large woody debris, channel bends and abrupt changes in channel geometry also contribute to flow resistance (Dingman, 1984). The flow resistance of the channel increases as the sum of all sources of channel roughness increases.

Disturbances such as major floods and large sediment inputs can modify bed topography, and so influence channel roughness. In gravel-bed rivers, low-gradient ( $<2$ per cent) reaches commonly display pool-riffle morphology, and disturbances can reduce the size and frequency of deep pools. Consequently, channel roughness becomes smoother, and the changes in bed topography caused by disturbance will be reflected in changes in velocity and shear stress distributions as well. Following input of a pulse of sediment and debris, river channel processes and forms will adjust and evolve towards a new equilibrium state. The trajectories and timing of these adjustments involved in 'recovery' following disturbance are of interest to both

\footnotetext{
* Correspondence to: M. A. Madej, US Geological Survey Western Ecological Research Center, 1125 16th Street, Room 207, Arcata, California 95521, USA 
geomorphologists and aquatic ecologists. Disturbance to a dynamically stable riffle-pool channel which results in aggradation leads to riffles becoming more extensive, pools becoming smaller and shallower, and bed material textures becoming finer (Lisle, 1982; Jackson and Beschta, 1984). The fluvial system may be interpreted as exhibiting non-linear system behaviour and, hence, system trajectories are dependent upon instantaneous system states (Lane and Richards, 1997). Thus, an understanding of the sequence of configurations (in this case, the sequence of development of longitudinal thalweg profiles) through which the system evolves is essential in order to explain system behaviour (Lane and Richards, 1997).

The thalweg profile is influenced by the distribution of pools and riffles. The distribution of the gravel bar units that constitute riffles, and their associated pools, can be 'free' or 'forced' (Seminara and Tubino, 1989). Freely formed pools result from the fluvial hydraulics of the stream and patterns of flow convergence and meander development. Several studies have shown that in alluvial, self-formed channels, pool spacing is between five and seven times the channel width (Leopold et al., 1964; Keller and Melhorn, 1978). Pools can also be 'forced' (Lisle, 1986; Montgomery and Buffington, 1997) by scour around obstructions such as large woody debris, boulders and bedrock outcrops. Forced pools may be spaced closer than pools in self-formed channels (Montgomery et al., 1995). The distribution of forcing elements (large woody debris, boulders and bedrock outcrops) in many catchments is random and, consequently, no regular spacing between forced pools would be expected. It follows that different patterns of pool distribution (random or regular) may be used to determine the relative importance of different formative mechanisms.

The conceptual model proposed in this paper is that spatial structure in a longitudinal profile may be attributed to the type of material dominating channel boundary characteristics (sediment, woody debris or bedrock) and the time elapsed since the last major disturbance (due to floods or landslides, for example). Spatial structure in a thalweg profile is defined by several elements, including the presence of regular oscillations in bed topography (primarily due to pools and riffles), the strength of spatial autocorrelation between points in the channel bed, and the length of channel bed exhibiting autocorrelation (such as the length of a riffle crest). Immediately following disturbance, a river that can readily reorganize the dominant channel-forming materials in the channel bed may exhibit low variation in bed elevations and no regular pattern in bed topography. This would be the case, for example, in rivers where the bed material size is much less than the bankfull depth, or the length of key elements of woody debris is less than the channel width. However, with increasing time since disturbance, variation in bed topography will increase and the arrangement of spatial structure in the bed profile will become more regular. In contrast, no regularly spaced features in the bed will evolve in rivers that cannot readily reorganize the dominant channel-forming materials. This would be the case, for example, in rivers where the bed particle size approaches bankfull depth, or length of large woody debris is greater than the channel width and forced pools dominate. A random pattern of bed topography would be expected in a stream with many forced pools, whereas a regular pattern would be expected if pools were freely formed by the hydraulics of converging flow in an alternate bar river.

\section{REVIEW OF EXISTING APPROACHES}

Several methods of quantifying longitudinal channel bed patterns, and especially the presence of pools, have been developed. A technique frequently used in the United States to determine the distribution of pools is 'habitat typing' in which an observer walks the channel and uses a tape to measures the length of pools, riffles and other features (US Forest Service, 1992). There are, however, problems with habitat typing including high operator variability, lack of replicability and discharge dependency.

O'Neill and Abrahams (1984) suggested an objective method of identifying pools, but their approach determines only numbers of pools and riffles and it is still based on a single threshold measure of the deepest part of the pool. Peterson et al. (1992) attempted to set target conditions for pool frequency, but they admitted that the criteria used to define pools varied considerably among studies that applied their analysis. Hogan and Church (1989) suggested that depth and velocity distributions across the entire channel area could be used to support more complete habitat assessment. In practice, these distributions are functions of river stage and they are, in any case, difficult to measure for high flows.

Copyright (C) 1999 John Wiley \& Sons, Ltd.

Earth Surf. Process. Landforms 24, 1153-1169 (1999) 
The problem with all these approaches is that they assume that the pool is the only feature of interest in channel spatial structure, and that a pool can be objectively defined and consistently identified. In addition to pools, the degree of variation of channel bed elevations is an important component of channel boundary conditions, which cannot be derived simply from an analysis of maximum pool depths. In practice, two pools with equal maximum depths may have very different bed morphologies and may have been formed by different fluvial processes.

To monitor pool depths independently of discharge, Lisle (1987) adapted the concept of residual water depth that was first introduced by Bathurst (1981). The residual pool depth $\left(d_{\mathrm{r}}\right)$ is the depth of water in the pool below the elevation of the downstream riffle crest. This can be thought of as the water depth that would be present in the river if stream flow were zero and the riffle were impermeable. The distribution of residual water depths along the entire longitudinal profile incorporates thalweg topography and provides more useful information than any analysis of the pools alone. For example, Lisle (1995) found comparison of the standard deviation of residual water depths useful in identifying and assessing morphological differences between two streams due to differences in their coarse woody debris loadings. However, this approach has not to date been applied to larger rivers with different disturbance histories.

Spatial statistics provide an objective technique to detect the presence of channel bed features, such as pools or riffles. Richards (1976) used spatial series analysis to quantify oscillations in channel width and in the longitudinal bed profile. Robert and Richards (1988) demonstrated the usefulness of semivariograms to model sand bedforms, and Robert (1988) used them to define micro-scale bed relief ( $5 \mathrm{~mm}$ spacing along a $6 \mathrm{~m}$ transect) in gravel-bed streams. However, two fundamental problems exist in the use of the semivariogram to define patterns in bed topography. First, there is no simple way of determining confidence limits analytically (Robert and Richards, 1988) and, second, they have limited utility in detecting areas of similar bed elevation, such as a riffle crest. While spectral analysis has been used to define patterns of bed elevation in sand-bed channels, it is difficult to place a physical interpretation on the results (Robert and Richards, 1988). Murray and Paola (1996) discuss the limitations of using spectral analysis and fractal methods to determine the downstream spatial structure of fluvial patterns. For example, similar power law spectral behaviour can be produced by systems that are very different in character. Robison and Beschta (1989) used correlograms to define the spatial autocorrelation of low flow depths in several small streams with high coarse woody debris loadings. The results showed no significant pattern in the distribution of low flow depths for their study reaches, which were located in pristine, forested streams with many forced pools. Also, although spatial statistics have been used to characterize channel morphology at a given time, their use in monitoring temporal trends of morphological change following channel disturbance is much more limited.

On the basis of this review of past research, it may be concluded that changes in longitudinal profiles over decadal time-scales have not to date been studied systematically. To address this gap in knowledge, this paper evaluates several potential approaches to quantifying changes in thalweg morphology following disturbances due to large sediment inputs. The paper examines the potential for using the distribution of residual water depths as a tool for monitoring the bed morphology of disturbed channels. It employs spatial autocorrelation analysis of the morphological data to depict temporal changes in the spatial structure of bed topography. Within the temporal framework, spatial statistics are used to characterize whether the longitudinal pattern of bed elevations is random or regular, and to estimate the maximum morphological variance or similarity in different parts of the channel.

\section{FIELD AREA}

The Redwood Creek catchment is located in the northern Coast Ranges of California, USA (Figure 1), and is underlain by rocks of the Franciscan Assemblage, mostly sandstones, mudstones and schist. The basin has an area of $720 \mathrm{~km}^{2}$ and receives an average of $2000 \mathrm{~mm}$ of precipitation annually, most of which falls as rain between October and March. Total basin relief is $1615 \mathrm{~m}$ and the average hillslope gradient is 26 per cent. Redwood Creek is a gravel-bed river with a length of $100 \mathrm{~km}$ and channel gradients ranging from 12 per cent in the headwaters to $0 \cdot 0 \cdot 1$ per cent in the lower reaches. Channel gradient is less than 2 per cent in the lowest $80 \mathrm{~km}$ of Redwood Creek and the bed morphology is characterized by pools and riffles. 


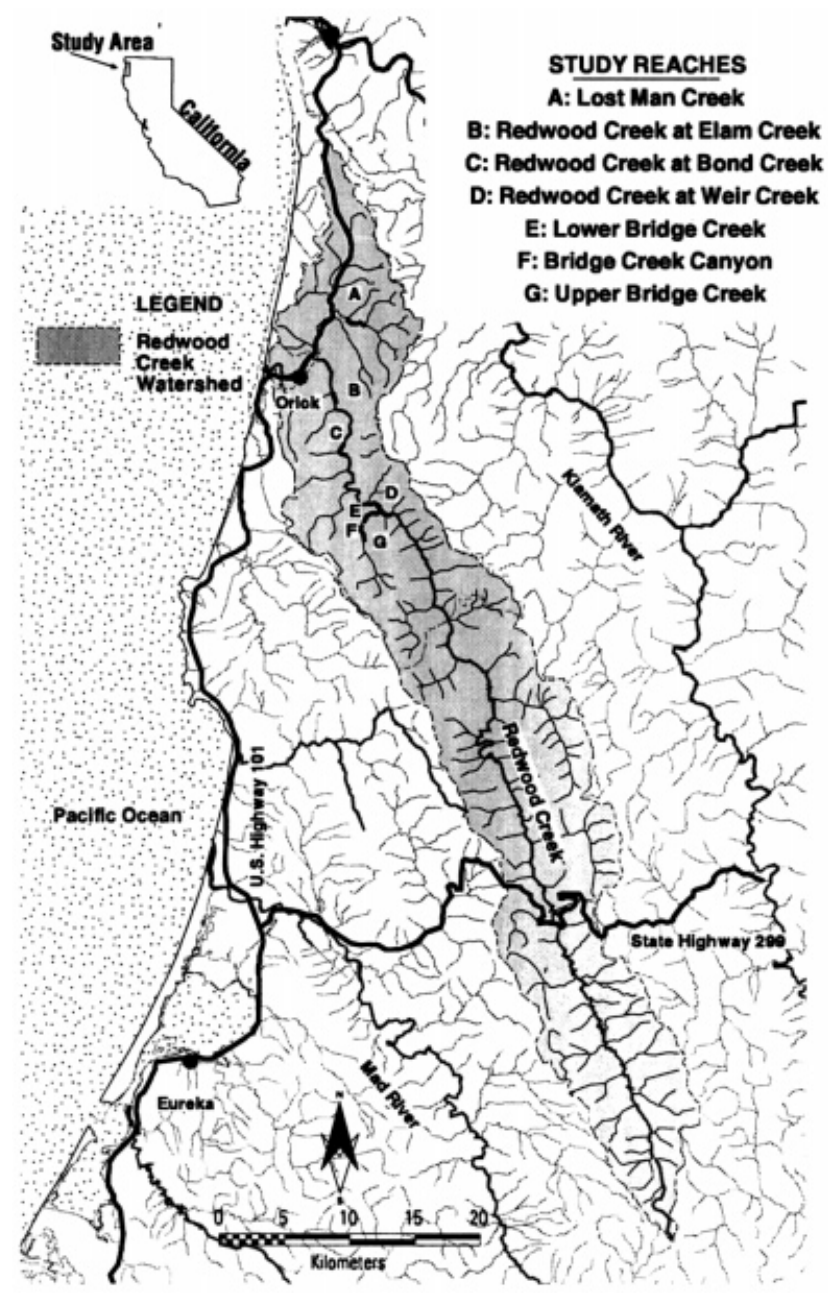

Figure 1. Location map of the Redwood Creek catchment showing the three study reaches on the mainstem of Redwood Creek, three in Bridge Creek and one in Lost Man Creek

Most tributaries are steep ( $>4$ per cent), but the four largest tributaries include low-gradient reaches with well developed pool-riffle morphology like that in the main stream. Two of the larger tributaries, Bridge Creek and Lost Man Creek, are included in this study. There is no pristine, low-gradient 'control' reach with which to compare the disturbed reaches. However, Lost Man Creek has experienced no land-use disturbances since it underwent timber harvesting and road construction during the 1960s. Hence, this stream was used for comparison with the study reaches.

Prior to 1945, 85 per cent of the Redwood Creek basin was forested with stands of redwood (Sequoia sempervirens) and Douglas fir (Pseudotsuga menziesii) (Best, 1995). These trees can reach $100 \mathrm{~m}$ in height and $3 \mathrm{~m}$ in diameter, and the large woody debris contributed by fallen trees affects the morphology of many streams. During the last four decades, large floods and extensive logging have resulted in widespread channel aggradation and bank erosion (Madej and Ozaki, 1996). A 50-year flood in 1964 caused extensive streamside landsliding, but no surveys are available during that period to quantify channel changes.

Following a 25-year flood in 1975, the channel beds of Redwood Creek and its tributary Bridge Creek were almost flat and featureless in many reaches. Between 1977 and 1997, longitudinal thalweg profiles of several reaches of Redwood Creek and Bridge Creek were resurveyed on several occasions to monitor the changes in 
Table I. Study reach characteristics

\begin{tabular}{|c|c|c|c|c|c|c|c|}
\hline & $\begin{array}{l}\text { Redwood at } \\
\text { Weir Creek }\end{array}$ & $\begin{array}{l}\text { Redwood at } \\
\text { Bond Creek }\end{array}$ & $\begin{array}{l}\text { Redwood at } \\
\text { Elam Creek }\end{array}$ & $\begin{array}{l}\text { Upper Bridge } \\
\text { Creek }\end{array}$ & $\begin{array}{l}\text { Bridge Creek } \\
\text { Canyon }\end{array}$ & $\begin{array}{c}\text { Lower Bridge } \\
\text { Creek }\end{array}$ & $\begin{array}{c}\text { Lost Mar } \\
\text { Creek }\end{array}$ \\
\hline Drainage area $\left(\mathrm{km}^{2}\right)$ & 523 & 585 & 605 & 25 & 27 & 30 & 20 \\
\hline Bankfull width (m) & 60 & 70 & 110 & 23 & 12 & 15 & 14 \\
\hline Bankfull depth (m) & $2 \cdot 2$ & $2 \cdot 0$ & 1.9 & 1.0 & 1.3 & 1.2 & 1.2 \\
\hline Channel gradient (\%) & 0.24 & 0.18 & $0 \cdot 15$ & $1 \cdot 24$ & 1.66 & $1 \cdot 12$ & 0.71 \\
\hline Profile length $(\mathrm{m})$ & 2500 & 2100 & 2530 & 550 & 670 & 400 & 810 \\
\hline $\begin{array}{l}D_{50}(\mathrm{~mm}) \\
\text { Influence }\end{array}$ & 22 & 18 & 15 & 30 & 60 & 32 & 45 \\
\hline woody debris & Low & Low & Low & Moderate & High & Moderate & Moderate \\
\hline
\end{tabular}

pool distribution and depths as the morphology responded to the 1975 depositional event. The depth and frequency of pools in Redwood Creek increased between 1977 and 1995 (Madej, 1996; Madej and Ozaki, 1996) and pools are presently spaced about three channel widths apart in most of the study reaches. Channel cross-sectional changes were also monitored, and these have shown systematic spatial patterns of bank erosion, aggradation and subsequent degradation (Madej and Ozaki, 1996). Between 1977 and 1996, no flow exceeded a five-year recurrence interval. However, in 1997, a 12-year flood initiated many new debris flows that contributed large volumes of sediment to the rivers and triggered renewed aggradation in several reaches.

Seven study reaches, representing a range of channel morphologies and types, were established on Redwood Creek (three), Bridge Creek (three) and Lost Man Creek (one) (Figure 1). Reach characteristics are listed in Table I. Redwood Creek has low-sinuosity planform $(p=1.03$ to 1.10$)$ displaying alternate bars. Typical bar lengths are 350 to $500 \mathrm{~m}$. Mean particle size is small in comparison to depth, and the few pieces of in-channel large woody debris in the study reach are much shorter than the channel width. Upstream reaches of Redwood Creek aggraded following the 1975 flood, but have subsequently degraded (Madej, 1996). The study reach 'Redwood Creek at Weir Creek' is within this degrading segment of river. Farther downstream, Redwood Creek at Bond Creek and Redwood Creek at Elam Creek are two reaches that aggraded by an average of $0.6 \mathrm{~m}$ between 1975 and 1986, but subsequently degraded by about $0.3 \mathrm{~m}$ between 1986 and 1995 (Madej and Ozaki, 1996). The channel bed in these three study reaches aggraded slightly $(0 \cdot 1 \mathrm{~m})$ after the 1997 flood (Ozaki and Jones, 1998).

Bridge Creek is a gravel-bed stream which presently exhibits an alternate bar planform, with typical bar lengths of 150 to $200 \mathrm{~m}$. In 1954 and 1971, large woody debris was removed from the channel to salvage merchantable timber (Klein et al., 1987). Since 1971 the input of new large woody debris has been limited and, due to the extensive harvesting of streamside trees, the present debris loading is lower than it would be under pristine conditions. Although longitudinal profile surveys did not commence until 1986, field observations and examination of available aerial photographs indicate that Upper Bridge Creek received high sediment inputs in 1975. Cross-sectional monitoring shows that a great deal of sediment was transported out of the upper reach prior to 1986, but that only $0.2 \mathrm{~m}$ of further degradation occurred between 1986 and 1995 . In 1997 a debris flow delivered $13000 \mathrm{~m}^{3}$ of sediment and a great deal of large woody debris to the channel upstream of the upper surveyed reach and the channel aggraded locally as a result (Madej and Gibbs, 1998).

A narrow canyon, in which large woody debris, boulders and bedrock outcrops are common, separates the upper and lower reaches of Bridge Creek. In Lower Bridge Creek the channel degraded by $2 \mathrm{~m}$ between 1975 and 1986, but the rate of downcutting had decreased to 0.1 m/yr by 1996 (Madej and Gibbs, 1998). In 1986, woody debris loading was low in Lower Bridge Creek, but landslides generated by the 1997 storm event contributed many new pieces of large woody debris to this reach.

\section{FIELD METHODS}

Three to five resurveys of the study reaches were performed between 1977 and 1997 to document the development of bed morphology, and especially pools and riffles, following the 1975 flood. The US 
Geological Survey in the summer of 1977 surveyed a longitudinal thalweg profile of the lowest $22 \mathrm{~km}$ of Redwood Creek. The author resurveyed selected reaches of this area in 1983, 1986, 1995 and 1997. Surveys of Bridge Creek, reported by Klein et al. (1987), were conducted in 1986, and by the author in 1995 and 1997. Surveyed long-profiles began and ended at riffle crests and survey distances were measured along the centreline of the high-flow channel. Elevations of the thalweg and water surface were established using either an automatic level and stadia rod, or an electronic distance meter and target. Survey readings were taken at all breaks in slope of the channel bed in order to characterize all major morphologic features (i.e. top, middle and base of riffles and pools) along the thalweg. The spacing of survey points averaged $15 \mathrm{~m}$ in Redwood Creek and $4 \mathrm{~m}$ in Bridge Creek. In Redwood Creek, surveyors used staff plates at three gauging stations and 20 permanent bench marks established for channel cross-sectional monitoring as controls on surveying accuracy. The total error in elevation between the surveys was less than 0.2 per cent $(0.8 \mathrm{~m})$. The length of each surveyed profile was 20 to 55 channel widths (400 to $2500 \mathrm{~m}$, depending on the stream reach; Table I).

Channel planform patterns and bar lengths were mapped from aerial photographs at a scale of 1:6000, dating from 1978 and 1997. Unfortunately, bar lengths on the two dates could not be compared quantitatively because the discharge in the 1997 photographs is six times higher than that in the 1978 photographs. However, bar shape and location in the channel were compared qualitatively. Bar lengths measured on the 1978 photographs (taken during summer low flow) were used to calculate mean bar lengths in Redwood Creek.

\section{ANALYTICAL TECHNIQUES}

The distribution of residual water depths for each longitudinal survey was calculated using the method of Lisle (1987). First, bed elevations between survey points were linearly interpolated to create a common base from which to compare profiles for different years. A $5 \mathrm{~m}$ spacing was used for Redwood Creek, where channel widths vary from 60 to $110 \mathrm{~m}$, in order to define all but the finest features of longitudinal bed topography. A $3 \mathrm{~m}$ spacing was employed for Bridge and Lost Man Creeks, where widths vary from 12 to $23 \mathrm{~m}$. A computer program was written to plot the profiles, convert the surveys into standardized data sets, calculate the distribution, mean and standard deviation of residual water depths, and compute the percentage of channel length occupied by riffles. For this purpose, riffle points were defined as points where the residual depth was zero. Figure 2 a shows an example of a surveyed thalweg profile and Figure $2 b$ illustrates the profile data transformed into residual water depths. Variability in bed elevations was evaluated using the standard deviations of residual water depth for each study reach. The significance of differences in the means, medians and distributions of residual water depth distributions from successive surveys was examined using the Student's $t$, Mann-Whitney and Kolmogorov-Smirnov tests, respectively.

The spatial distribution of pools and riffles is also of geomorphological interest, but the residual depth distributions do not contain information on the spatial ordering of pools within the fluvial system. To analyse spatial patterns in the distributions of pools and bed elevations, residual water depths were analysed by the use of the Moran's $I$ spatial autocorrelation coefficient (Legendre and Fortin, 1989). The formula for $I$ at distance class $d$ is:

$$
I(d)=\frac{n \sum \sum w_{i j}\left(y_{i}-\bar{y}\right)\left(y_{j}-\bar{y}\right)}{W \sum\left(y_{i}-\bar{y}\right)^{2}}
$$

where $y=$ residual water depth at points $i$ and $j$ in the channel, and $\bar{y}=$ mean residual depth. All summations are for $i$ and $j$ varying from 1 to $n$, the number of data points, but exclude the cases where $i=j$. The $w_{i j}$ 's take the value of 1 when the pair $(i, j)$ pertains to the distance class $d$, and 0 otherwise. $W$ is the number of pairs of points used in computing the coefficients for the given distance class. Moran's I may be positive or negative, with values usually ranging between -1 and +1 . Moran's $I$ compares values for pairs of points (residual

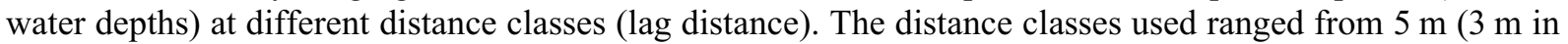
Bridge and Lost Man Creeks) to one-third of the long-profile length, or about $800 \mathrm{~m}$ in Redwood Creek. 

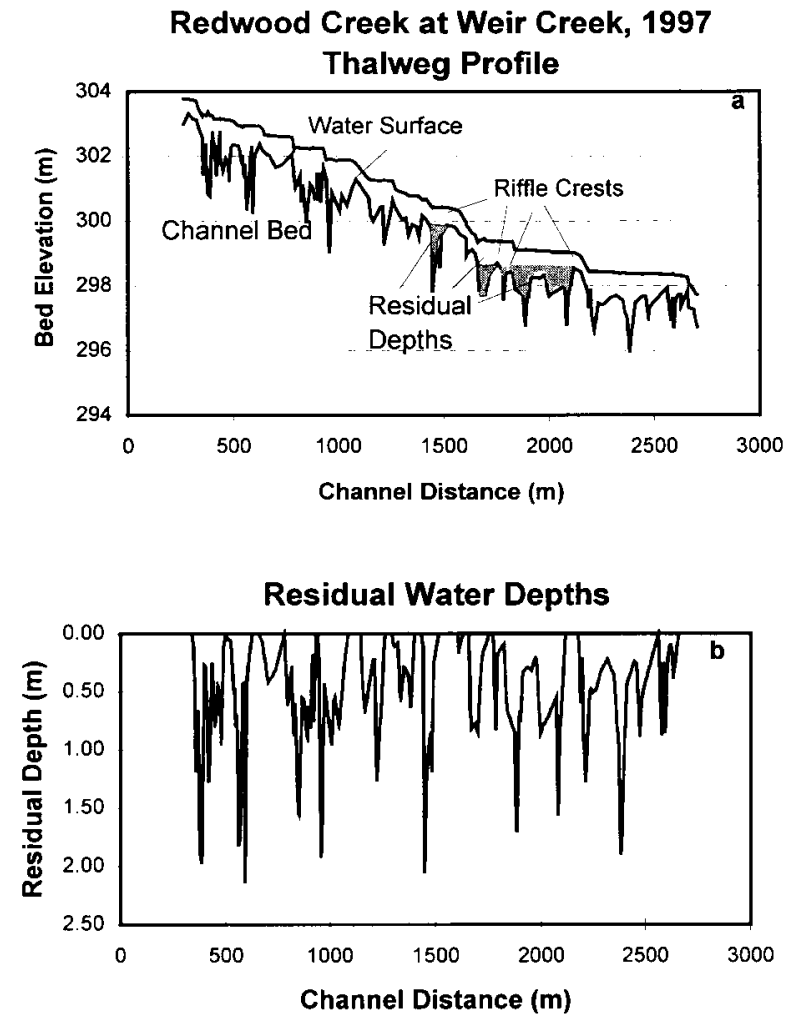

Figure 2. Examples of longitudinal thalweg profile plots showing (a) how residual water depths are calculated and (b) the corresponding residual water depth plot for Redwood Creek at Weir Creek

Surveys from 1977 were not used in this analysis because the spacing of survey points was larger than in the other surveys, which would limit the ability of the correlograms to detect small bed features.

The spatial structure of the channel bed profiles was examined using correlograms. Correlograms are plots of autocorrelation values (in this case, Moran's $I$ ) in the ordinate against distances between pairs of thalweg survey points (lag distances). The characteristics of the correlogram shape, such as the spacing between peaks and troughs and the width of a peak, are associated with particular spatial structures (Legendre and Fortin, 1989). Positive correlation (points plotted above the 95 per cent confidence interval line on the correlogram) show distances at which residual water depths are similar to each other (for example, pools and pools, or riffles and riffles), whereas negative correlation (points plotted below the 95 per cent confidence interval line on the correlogram) show distances at which residual water depths are significantly different from each other (for example, pools and riffles). It is common for the first few points in a correlogram to be positively correlated up to a short lag distance. This distance represents the length of channel in which neighbouring points have similar residual water depths, such as the length of a riffle crest.

Correlograms were used in two ways. First, correlograms from different years were compared to identify temporal trends, through detecting the presence and scale of significant spatial autocorrelation of bed elevations. Second, correlograms were used to test whether the pattern of bed elevations was random or nonrandom. To test for spatial patterns, each set of residual water depths was randomized, and then a new correlogram was calculated. A chi-squared test was then used to compare the expected number of significant (positive or negative) and non-significant coefficients in the observed-values correlogram against those in the random correlogram. 


\section{Redwood Creek at Elam Creek}

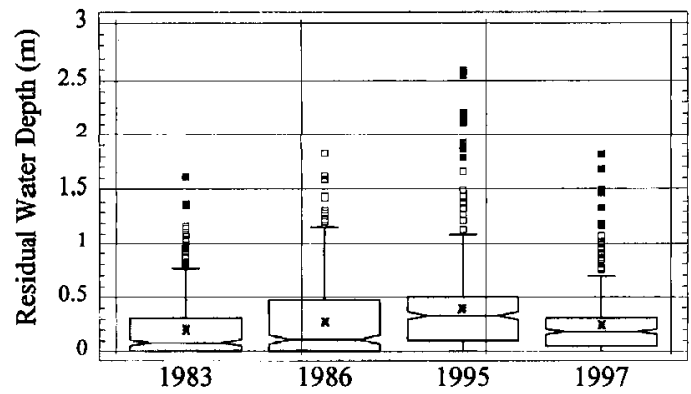

Redwood Creek at Bond Creek

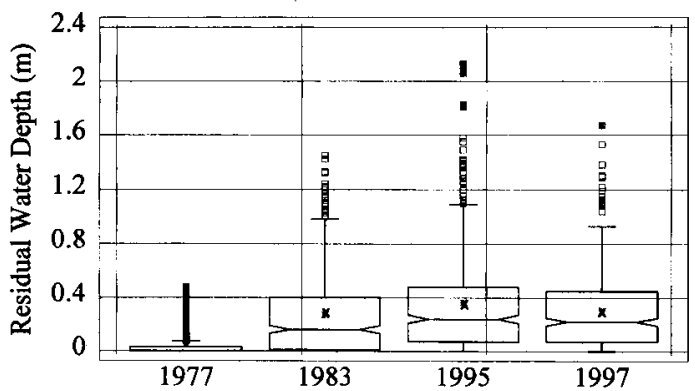

Redwood Creek at Weir Creek

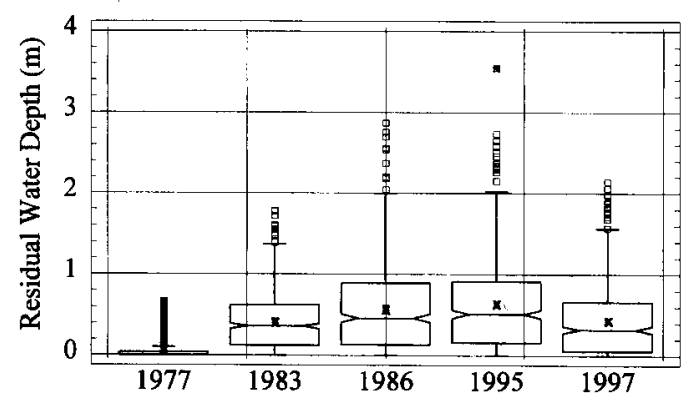

Figure 3. Box plots of residual water depths for Redwood Creek study reaches for the period 1977 to 1997 . The upper and lower lines of the box are the 75 and 25 percentiles of the residual water depth distribution, the notches and centreline show the median values, and the $\times$ sign is the mean of the distribution. The lowermost horizontal line (whisker) is drawn from the lower quartile to the smallest point within 1.5 interquartile ranges from the lower quartile. The top whisker is drawn from the upper quartile to the largest point within 1.5 interquartile ranges from the upper quartile. Values that fall beyond the whiskers, but within three interquartile ranges are plotted as individual points (outliers)

\section{Upper Bridge Creek}

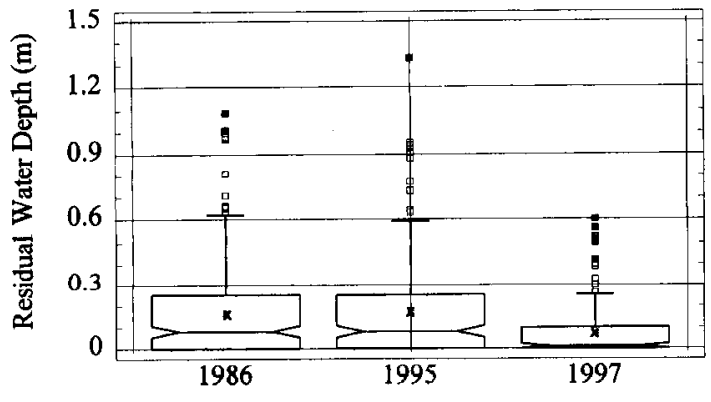

Bridge Creek Canyon

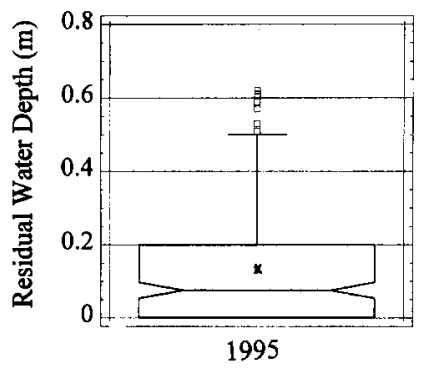

Lower Bridge Creek

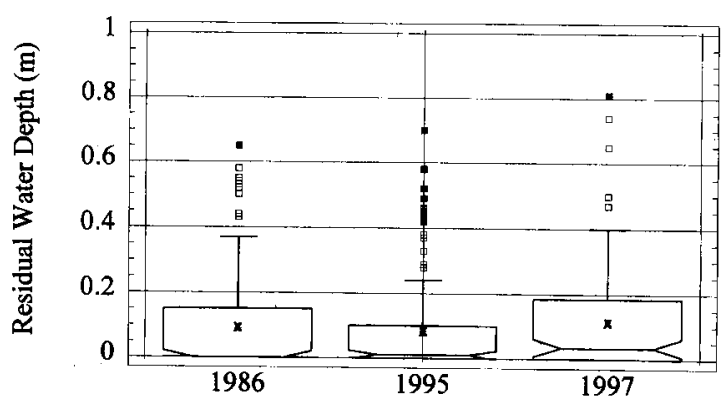

Figure 4. Box plots of residual water depths for Upper Bridge Creek, Bridge Creek Canyon and Lower Bridge Creek study reaches. See Figure 3 caption for explanation 


\section{Lost Man Creek}

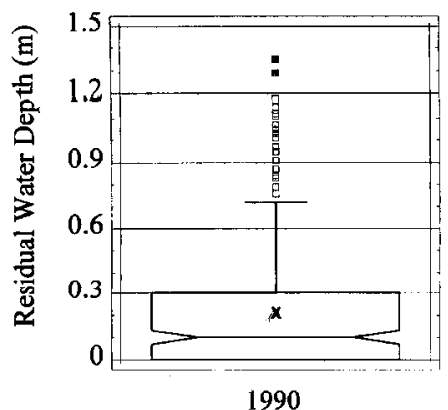

Figure 5. Box plot of residual water depths for Lost Man Creek study reach. See Figure 3 caption for explanation

\section{RESULTS AND DISCUSSION}

\section{Distribution of residual water depths}

Figures 3 to 5 present box plots of residual water depth in the study reaches on Redwood Creek, Bridge Creek and Lost Man Creek reach, respectively. In Redwood Creek, the mean residual water depths were very low in 1977, due to the impacts of the 1975 flood. The mean, median and maximum residual water depths then increased up until 1995, before decreasing, in response to the flood of 1997, to approximately their 1983 levels. Although the mean residual depths were not significantly different for some of the comparisons (for example, Redwood Creek at Bond Creek in 1983 and 1997; $t$-test with $\alpha=0.05$ ), the distributions for all reaches are significantly different from one another (Kolmogorov-Smirnov test, 95 per cent confidence levels). This finding demonstrates that consideration of the entire distribution of residual water depths can give a more complete picture of trends in the channel bed status than consideration of the means and maxima alone.

By the time of the initial profile survey in Bridge Creek, in 1986, Upper Bridge Creek had already recovered from the impacts of the 1975 flood, and only remnants of the flood deposits remained stored in the channel. Channel cross-sections reveal that about $0 \cdot 2 \mathrm{~m}$ of bed lowering took place between 1986 and 1995 , and show that a few pools increased in depth. Following the flood-associated debris flows of 1997, mean residual depth decreased in Upper Bridge Creek and was significantly lower than in previous years (Figure 4). The Bridge Creek Canyon reach displays a similar distribution of residual water depths to Upper Bridge Creek, although the mean residual depth is smaller. In Lower Bridge Creek, cross-section monitoring shows that the channel incised into the flood deposits by $2 \mathrm{~m}$ between 1975 and 1986, but little further bed degradation occurred after 1986. Mean residual water depths were not significantly different during this period, although maximum depths increased through time.

Figure 5 shows the distribution of residual water depths in Lost Man Creek, a stream unaffected by timber harvesting activities since the 1960s. The shape of the distribution is the same as in the other streams. However, it should be noted that the mean residual water depth in Lost Man Creek is greater than those in any of the Bridge Creek study reaches, even though Lost Man Creek drains a smaller catchment.

Figure 6 presents a plot of mean residual depths in the study reaches during the period 1977 to 1997. Mean depths increased between 1977 and 1995, although the rate of increase slowed after 1986. Mean residual depths in all study reaches decreased to values typical of the early 1980s following the 1997 flood, which had a recurrence interval of 12 years.

Figure 7 shows a graph of the percentage of channel length classified as riffle (residual depth $=0$ ) in the study reaches as a function of time. Trends in percentage riffle are the inverse of those for residual depths. Hence, the percentage of channel length occupied by riffles decreased in the years following the 1975 flood, 

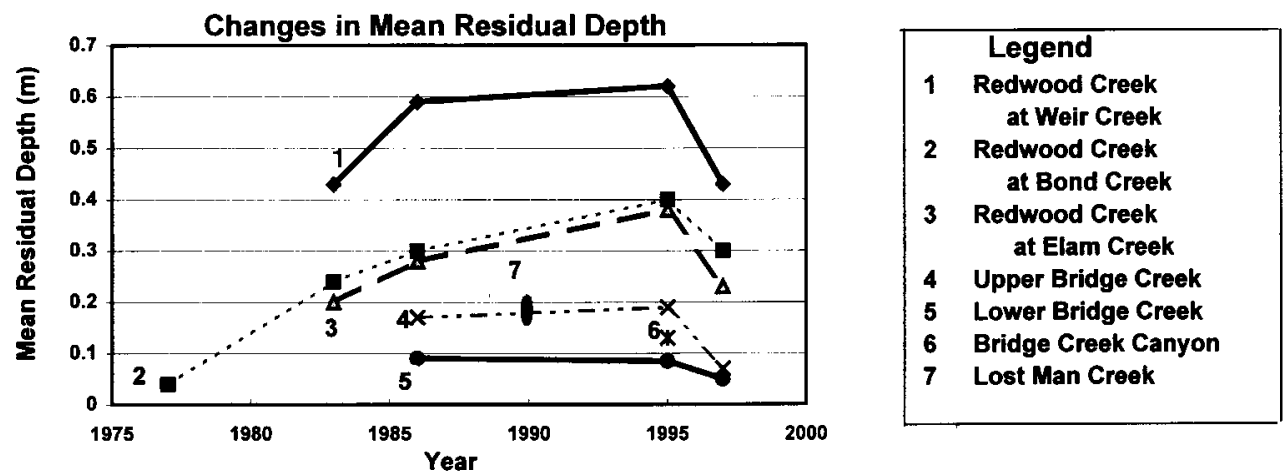

Figure 6. Mean residual water depth for each surveyed profile
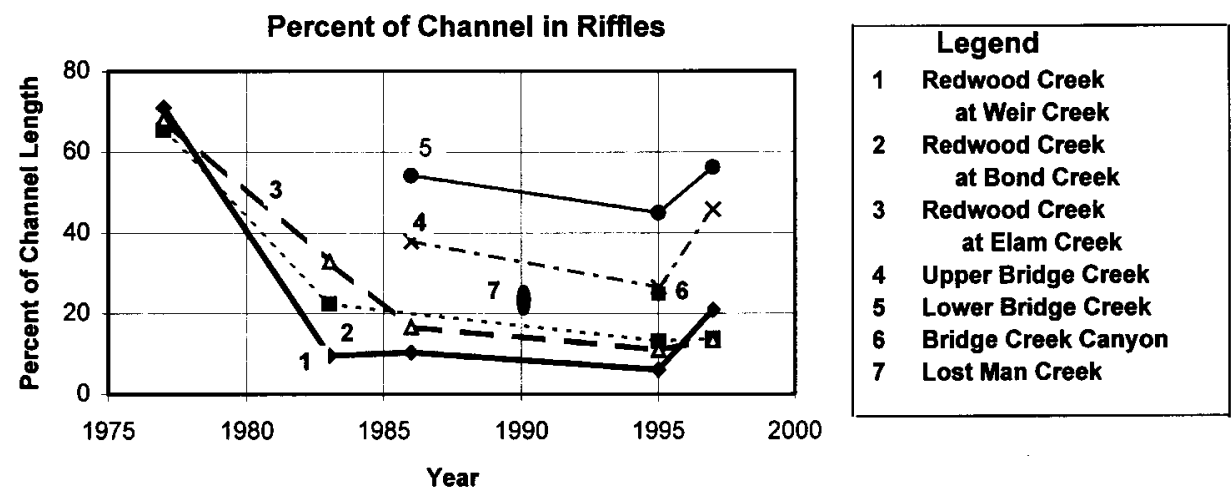

Figure 7. Percentage of channel length classified as 'riffle' in the thalweg profile surveys. Note: riffles are defined as points where the residual water depth equals zero

rapidly up until the mid-1980s, and then more slowly. The percentage of channel occupied by riffles increased to about mid-1980s levels following the 1997 flood.

The variance of bed elevations was evaluated using the standard deviation of the population of residual water depths (Figure 8). The underlying assumption is that increased variance in bed elevations reflects increased morphological diversity in the channel bed. In Redwood Creek, standard deviations increased rapidly for 10 years following the 1975 flood, but between the mid-1980s and 1995 standard deviations increased only slightly. This flattening of the curve may indicate that bed variability was approaching the upper limit of morphological diversity that can develop in this river under the present flow and sediment regimes. Standard deviations decreased in all reaches following the 1997 flood, although they remained higher than the levels observed in 1977 (immediately following the larger, 1975 flood).

In addition to these within-reach comparisons, it would be useful to compare the measurements made in all three creeks. However, to facilitate this the results must be standardized to remove scale effects. The statistic usually employed to allow scale-independent comparisons is the coefficient of variation [(standard deviation/ mean) $\times 100$ ]. However, plots of this statistic did not show any obvious pattern except that the magnitude of the standard deviation is frequently the same as the mean residual depth. Both mean residual depth and standard deviation change through time, but not necessarily at the same rate. As an alternative approach to removing scale effects, bankfull depth was used to normalize residual depths. Although bed topography was changing through time, the reach-averaged bankfull depth could be considered to be constant during the study period. Figure 9 shows a plot of the resulting variation index [(standard deviation of residual water depth/ 

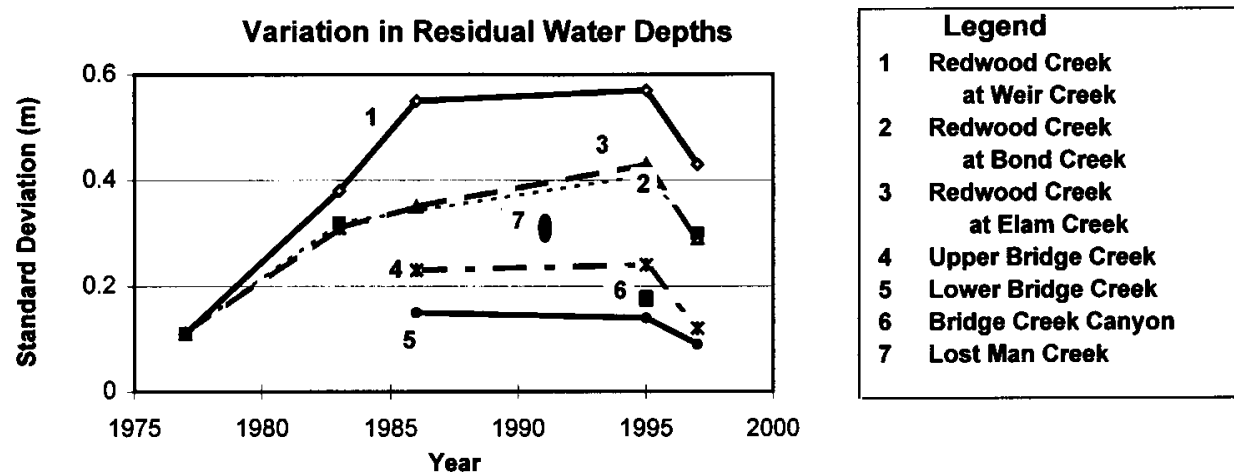

Figure 8. Variation in residual water depths in the thalweg profile surveys. The standard deviation of the population of residual water depths is plotted against time for the individual reaches

bankfull depth $\times 100$ ] as a function of time. The stream reaches with the smallest quantities of flood deposits remaining from the 1975 event (Upper Bridge Creek, Redwood Creek at Weir Creek, and Lost Man Creek) all plot above a value of 20, although the values for all the study reaches decrease following the 1997 flood. The general trend that emerges is that index values are higher at sites with better habitat conditions.

\section{Spatial autocorrelation in thalweg profiles}

Figures 10 to 15 display the correlograms for the repeat surveys of the study reaches. Most of the correlograms show significant positive correlations at short lag distances. This fine scale of correlation indicates similarity of neighbouring points, in other words, the length of channel bed with similar residual water depths (such as the length of a riffle). The length of this fine-scale correlation decreases through time in most study reaches. For example, in Redwood Creek at Weir Creek, the correlation distance decreases from $66 \mathrm{~m}$ in 1983, to $31 \mathrm{~m}$ in 1997 (Figure 10). Decreasing correlation distances may reflect reductions in the extent of riffles identified in the residual depth plot (Figure 7).

Significant positive or negative correlations in the correlograms at larger lag distances indicate the spacing of larger bed features. In 1983 in the Redwood Creek at Weir Creek reach, a positive correlation existed at $250 \mathrm{~m}$, which is about four times the channel width (Figure 10a). This corresponds to the average bar length measured in the 1978 aerial photographs. In 1986 residual depths were greater and two positive correlations

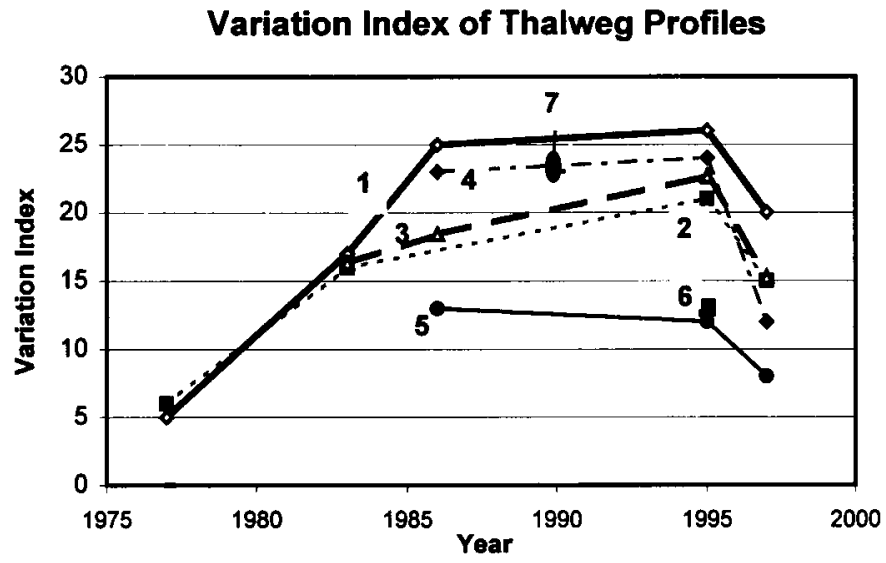

\begin{tabular}{|c|c|}
\hline & Legend \\
\hline 1 & $\begin{array}{r}\text { Redwood Creek } \\
\text { at Weir Creek }\end{array}$ \\
\hline 2 & $\begin{array}{l}\text { Redwood Creek } \\
\text { at Bond Creek }\end{array}$ \\
\hline 3 & $\begin{array}{l}\text { Redwood Creek } \\
\text { at Elam Creek }\end{array}$ \\
\hline 4 & Upper Bridge Creek \\
\hline 5 & Lower Bridge Creek \\
\hline 6 & Bridge Creek Canyon \\
\hline 7 & Lost Man Creek \\
\hline
\end{tabular}

Figure 9. Variation index for study reaches plotted against time. The variation index is defined as [(standard deviation of residual water depths/bankfull depth) $\times 100]$ 
Redwood Creek at Weir Creek, 1983

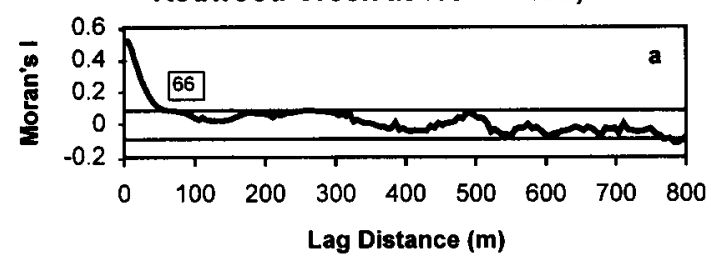

Redwood Creek at Weir Creek, 1986

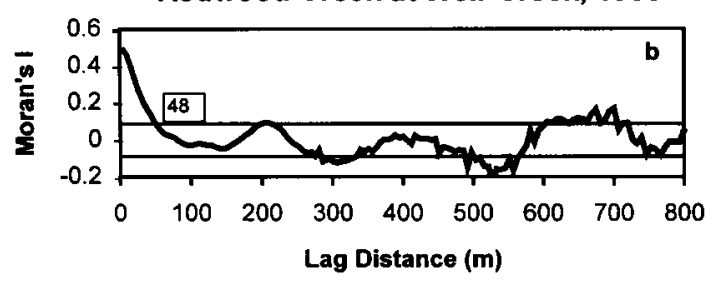

Redwood Creek at Weir Creek, 1995
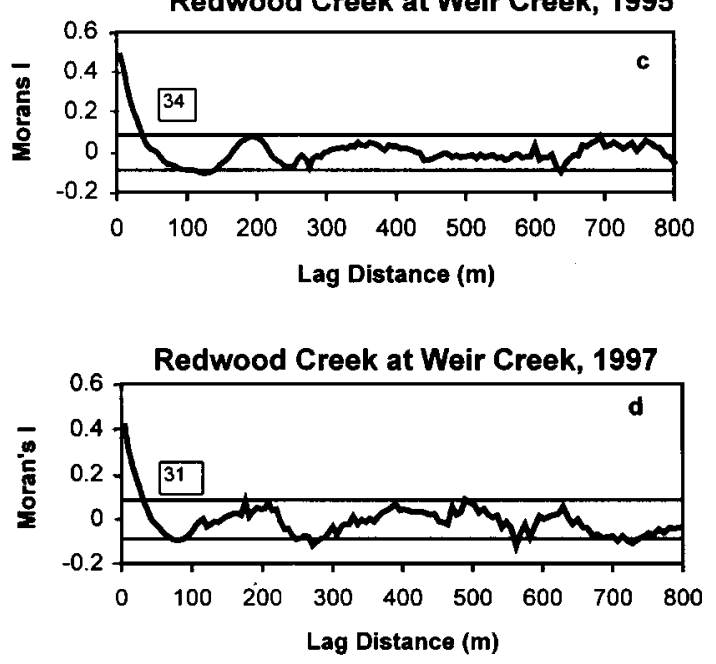

Figure 10. Correlogram based on Moran's I spatial autocorrelation coefficient for Redwood Creek at Weir Creek
Redwood Creek at Bond Creek, 1983
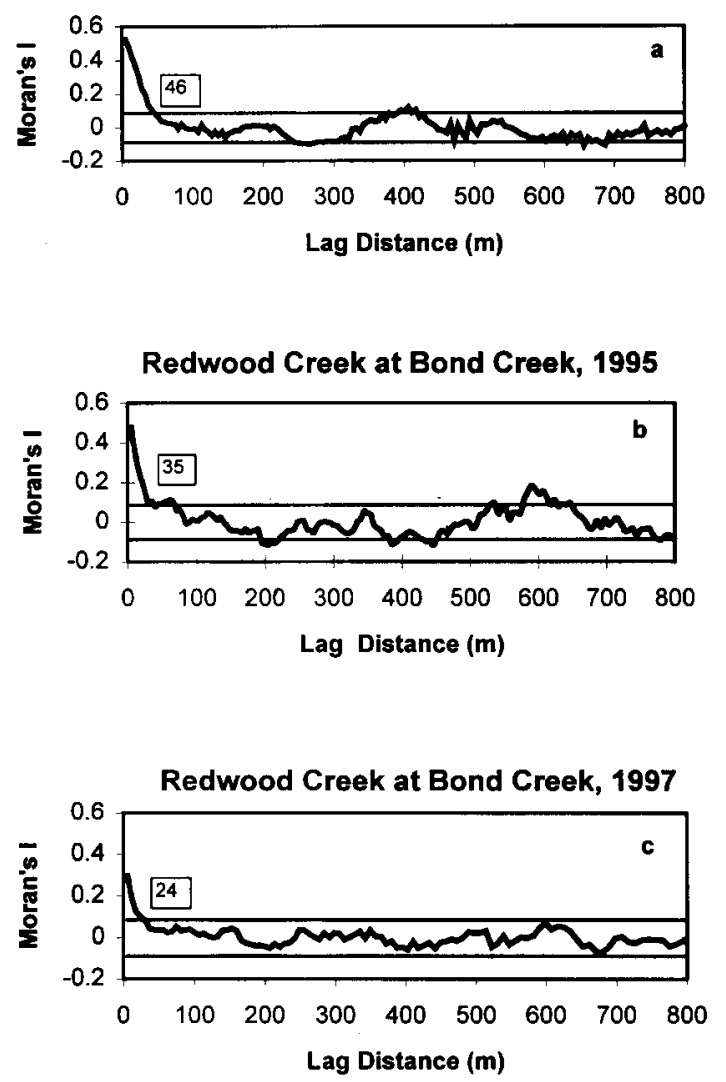

Figure 11. Correlogram based on Moran's I spatial autocorrelation coefficient for Redwood Creek at Bond Creek

occurred, at $200 \mathrm{~m}$ and $600-720 \mathrm{~m}$ (Figure 10b). Qualitative analysis of the aerial photographs revealed no obvious change in the planform of the river during this period, and it may be concluded that the second peak in the correlograms is probably an artifact due to the repetition of a $200-\mathrm{m}$ long feature. The positive correlation at $200 \mathrm{~m}$ remained present through to 1997 (Figure 10c and d).

Further downstream, in the aggrading reach, the history of bedform development differs significantly. In 1983 in the Redwood Creek at Bond Creek study reach, there was positive correlation at $400 \mathrm{~m}$, which is about five times the channel width (Figure 11a). This approximates to the average length of alternate bars in this reach measured on the 1978 aerial photographs. By 1995, the lag distance of the positive correlation had increased to $600 \mathrm{~m}$, or about eight times the channel width (Figure 11b), but following the 1997 flood, the distribution of residual water depths became more random. Aerial photographs taken in 1997 show that the planform still featured alternate bars, but expression of these bar units in the 1997 thalweg profile is weak (Figure 11c).

In 1983 in the downstream-most reach, Redwood Creek at Elam Creek, positive correlations existed at 180 and $350 \mathrm{~m}$, corresponding to 1.6 to three times the channel width, respectively (Figure 12a). The peak at $180 \mathrm{~m}$ had disappeared by 1986 (Figure 12b), but a significant correlation at 280-350 $\mathrm{m}$ was evident in all of 


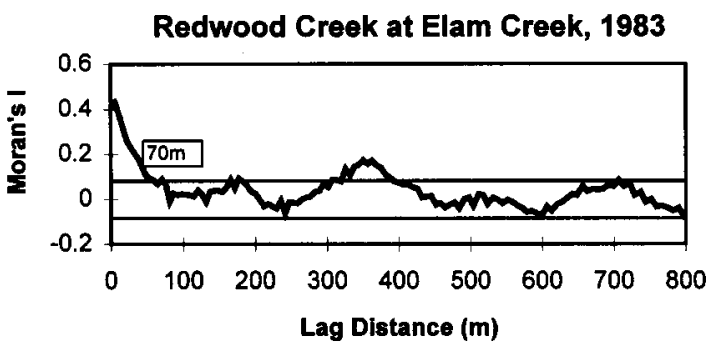

Redwood Creek at Elam Creek, 1986

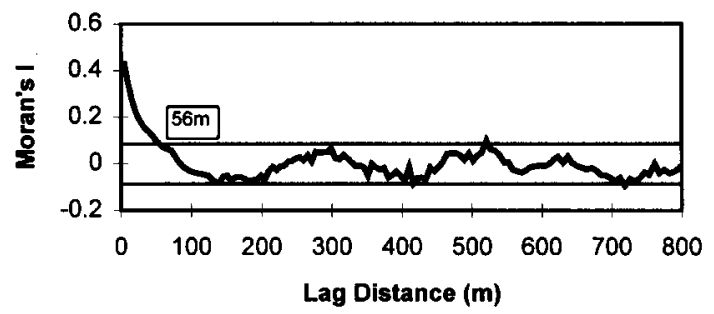

Redwood Creek at Elam Creek, 1995

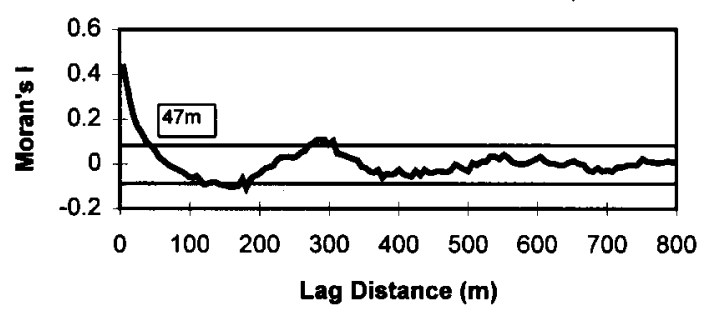

Redwood Creek at Elam Creek, 1997

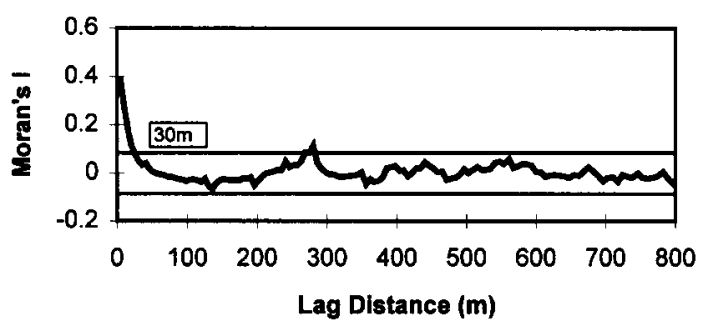

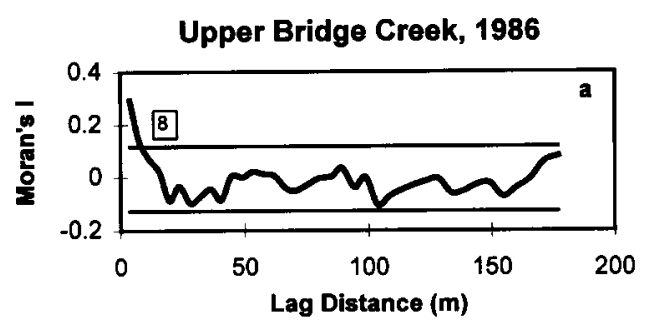
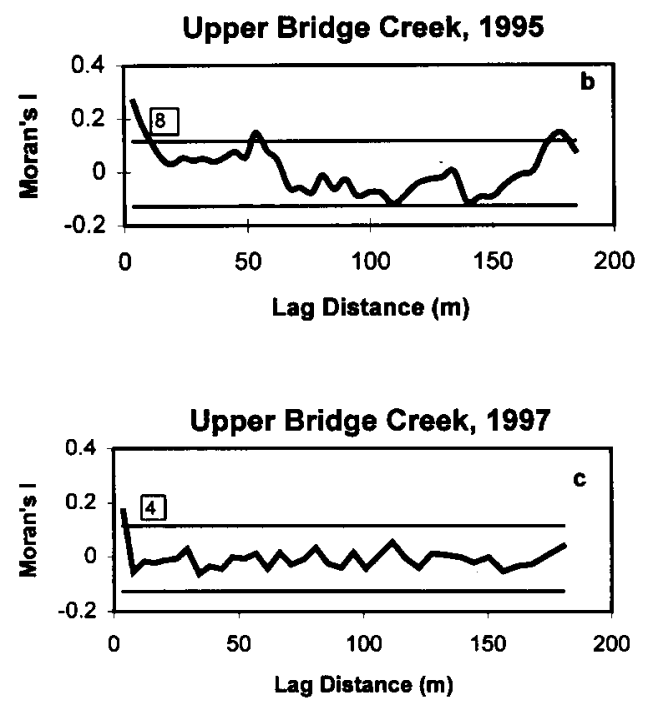

Figure 13. Correlogram based on Moran's I spatial autocorrelation coefficient for Upper Bridge Creek

Figure 12. Correlogram based on Moran's I spatial autocorrelation coefficient for Redwood Creek at Elam Creek

the surveyed profiles. Examination of available aerial photographs indicates that the average bar length in this reach is $400-500 \mathrm{~m}$. The finer scale of spatial autocorrelation in the thalweg profile actually corresponds to the pool spacing in this reach.

In Upper Bridge Creek the degree of organization of the channel bed (defined as detectable, regularly spaced features in the channel) increased between 1986, when no significant positive correlations were detected (Figure 13a), and 1995, when significant positive correlations appeared at $55 \mathrm{~m}$ and $180 \mathrm{~m}$ (Figure 13b). The correlation at $55 \mathrm{~m}$ corresponds to the most common spacing of riffle crests, while the correlation at $180 \mathrm{~m}$ corresponds to the length of alternate bar units in Upper Bridge Creek (150-200 m). The lack of regularly spaced alternate bars in this reach in 1986 is unsurprising because, historically, the high loading of large woody debris would have generated numerous, random irregularities in bed topography. Recently, inputs of woody debris have consisted of shorter, smaller pieces and the forced features produced by this type 
Lower Bridge Creek, 1986

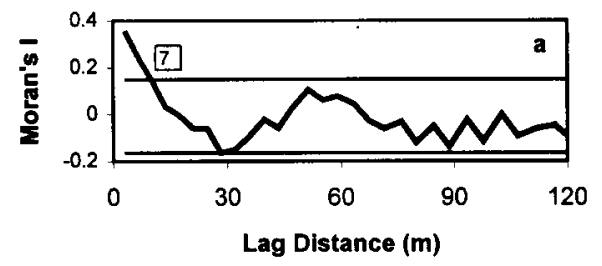

Lower Bridge Creek, 1995

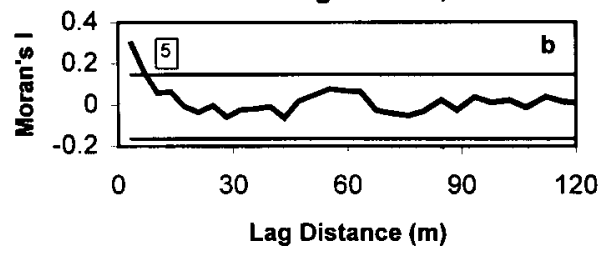

Lower Bridge Creek, 1997

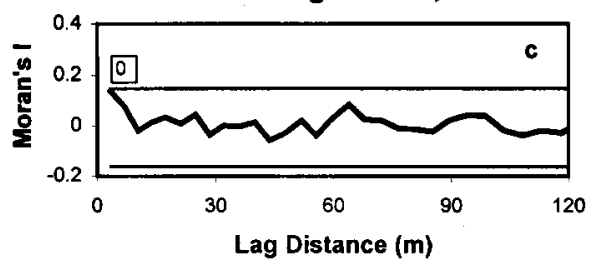

Figure 14. Correlogram based on Moran's I spatial autocorrelation coefficient for Lower Bridge Creek
Bridge Creok Canyon, 1995

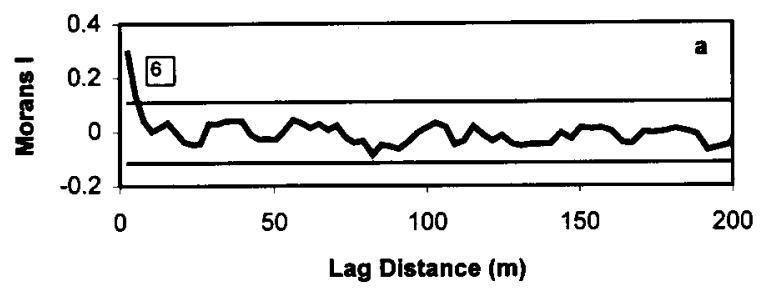

Lost Man Creek, 1990

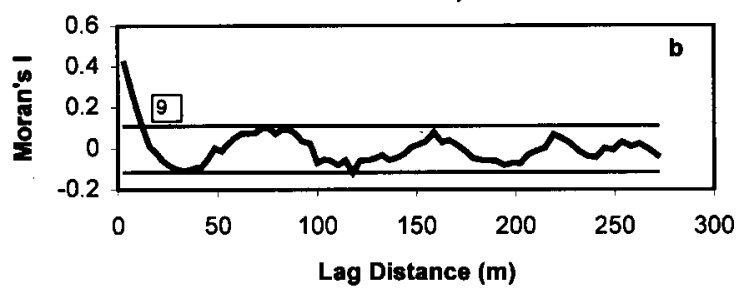

Redwood Creek at Weir Creek, 1995 Randomized Residual Water Depths

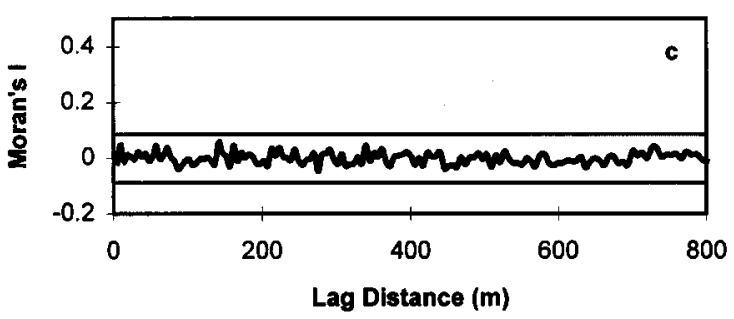

Figure 15. Correlogram based on Moran's I spatial autocorrelation coefficient for the Bridge Creek Canyon reach, Lost Man Creek, and a randomized set of residual water depths based on data from Redwood Creek at Weir Creek, 1995

of debris have not persisted. This is the case because moderate flows have been competent to entrain the wood, either reorganizing it into regularly spaced features or transporting it downstream. By 1995 the abundance of large woody debris compared to natural conditions was reduced to the point that forced pools and bars were no longer prevalent. However, the introduction of a great deal of sediment and large wood following the flood and debris flow of 1997, resulted in the distribution of residual water depths returning to a more random pattern in 1997 (Figure 13c). This residual depth distribution shows no significant correlation at lag distances greater than $4 \mathrm{~m}$.

No strong bed features with lag distances greater than a few metres appeared in any of the correlograms for Lower Bridge Creek (Figure 14), which is consistent with the fact that its planform has never exhibited well developed bars. Following the 1997 flood, and its associated inputs of sediment and woody debris, even the fine-scale autocorrelation between neighbouring points that was present in 1986 and 1995 had disappeared and the thalweg profile was completely random (Figure 14c).

Three further correlograms were formulated to exemplify the patterns of autocorrelation associated with particular bed morphologies and to support statistical testing of the significance of autocorrelation patterns observed at the study reaches (Figure 15). The correlogram for canyon reach of Bridge Creek (Figure 15a) has no significant correlations beyond a lag distance of $6 \mathrm{~m}$. This indicates a lack of regular features in the bed 
that is consistent with the actual configuration of the bed, which exhibits a few small, irregularly spaced bars and forced pools scoured around boulders, bedrock outcrops and large woody debris.

At Lost Man Creek, neighbouring points are significantly correlated up to a lag distance of $9 \mathrm{~m}$ and a regular structure is apparent in the correlogram at a spacing of about $80 \mathrm{~m}$ or six times the channel width (Figure 15b). These autocorrelations are representative of morphological features in the channel, which has only small pieces of woody debris and in which free riffle bars are well developed. It should be noted that under pristine, unlogged conditions large woody debris would probably be more abundant in this creek and this would influence channel morphology through generating more forced features and a more random pattern of bed topography.

Figure 15c shows the correlogram for a randomized set of residual water depths, based on the observed actual values plotted in Figure 10c. This is one example of the randomized sets that were created in the study for each surveyed profile. A chi-squared test, with a significance level $\alpha=0 \cdot 05$, was used to establish whether the actual and randomized residual depth distributions were significantly different. The results confirmed that spatial organization in several profiles was not significantly different from a random pattern. This was the case at Redwood Creek at Weir Creek in 1983, Redwood Creek at Bond Creek in 1997 and all the Bridge Creek profiles.

Numerical modelling of alluvial channels suggests there should be substantial elongation of alternate bar wavelength during morphological evolution from initial instability to fully developed, stable bars (Nelson, 1990). The correlograms generated in this study demonstrate that the large flood and sedimentation event of 1975 initiated morphological instability in Redwood Creek and suggest that a regular bed topography was reestablished during the subsequent decade. They do not, however, provide clear evidence that the wavelength of alternate bars elongated during the recovery period. The trend towards development of regularly spaced bar features was interrupted by a further flood in 1997. In fact, following this event, the degree of organization in the bed topography was reduced and positive correlations were only found at shorter lag distances. In most study reaches, positive autocorrelations were found at a spacing of about three channel widths, which corresponds to the average pool spacing, whereas alternate bar lengths were four to six times the channel width. It appears that, in this fluvial system, pools occur more frequently than the spacing of alternate bars would suggest. This is probably due to the presence of 'forcing' elements, such as large woody debris.

\section{DISCUSSION AND CONCLUSIONS}

This study used a statistical analysis of series of residual water depths to quantify changes in the pattern and variability of channel bed topography at a reach scale. During the 22 years following a large flood in 1975, the distributions of residual water depths changed significantly. Mean residual water depth and depth variability increased through time, while the length of channel occupied by riffles decreased, resulting in an increase in the degree of bed heterogeneity with the time since disturbance. Following the 1997 flood and associated sediment inputs, some of this heterogeneity was lost because variability in the thalweg profiles decreased markedly.

The use of spatial statistics to define morphological structure was found to be a promising technique for objective monitoring of changes in bed topography following disturbance. Study reaches represented a range of channel types, and the spatial analysis successfully identified the scales of autocorrelation associated with different bedforms and bed features. The length of fine-scale positive correlation decreased through time, perhaps corresponding to the decrease in the length of riffle crests that was documented in the surveyed profiles. Coarser-scale correlations were shown to correspond to the length of alternate bar units in the channels (four to six times the channel width) and to pool spacing (about times the three channel width). Pools are more frequent in Redwood Creek than might be expected in a free alternate bar system because of the presence of large woody debris and other obstructions that generate forced pools.

The results presented here provide a basis upon which to compare variability of longitudinal profile patterns in different sized streams and in response to disturbance by large floods and associated inputs of sediment and woody debris. Variation in both residual water depths and their spatial characteristics can be used to characterize the response of channel bed pattern to disturbance and the generation of significant 
spatial patterns during recovery from disturbance. The capability of the channel to remobilize inputs of woody debris and sediment determines the rate and degree of subsequent bed organization. The development of longitudinal patterns through time indicates the self-adjusting nature of river channels, by which fluvial processes order random inputs of sediment and debris from hillslope processes into spatially organized, fluvial bedforms and features. Stream reaches which could readily remobilize hillslope inputs (particle size was much less than bankfull depth, and length of large woody debris was less than channel width) increased both bed heterogeneity and spatial organization in the decades following disturbance. The analysis reported here only considered variation in the downstream direction. It would be useful in future to extend the analysis to consider changes in the cross-channel dimension, although, in the Redwood Creek basin, lateral channel changes are frequently constrained by narrow valley bottoms and bedrock outcrops and the planforms of the study reaches did not change markedly during the monitoring period. Despite this constraint, the longitudinal expression of alternate bar units became stronger with increasing time since disturbance.

\section{ACKNOWLEDGEMENTS}

Many people helped on the survey crews over the years, and I especially wish to thank Randy Klein, Vicki Ozaki, David Best, Deadra Knox, Greg Gibbs, Julie Miller, Brian Adkins, Brian Barr, Natalie Cabrera, Anna Bloom and Tera Curren for the long, wet hours of surveying, and the longer, drier hours of data analysis. Dwain Goforth developed the computer software to analyse longitudinal thalweg surveys. I am grateful to Gordon Grant, Julia Jones, Tom Lisle, Vicki Ozaki and the anonymous reviewers for their insights and helpful comments on a draft of this manuscript. Finally, I would like to thank Colin Thorne, Paolo Billi and Massimo Rinaldi for organizing the symposium session at Bologna and for the coordination and editing of this Special Issue.

\section{REFERENCES}

Bathurst, J. C. 1981. 'Bar resistance of gravel-bed streams - Discussion', American Society of Civil Engineers, Journal of the Hydraulics Division, HY10, 107, 1276-1278.

Best, D. 1995. 'History of timber harvest in the Redwood Creek basin, Northwestern California', Chapter C in Nolan, K. M., Kelsey, H. M. and Marron, D. C. (Eds), Geomorphic processes and aquatic habitat in the Redwood Creek Basin, northwestern California, US Geological Survey Professional Paper 1454.

Dingman, S. L. 1984. Fluvial Hydrology, W. H. Freeman and Co, New York, 383 pp.

Hogan, D. L. and Church, M. 1989. 'Hydraulic geometry in small, coastal streams: progress toward quantification of salmonid habitat', Canadian Journal of Fisheries and Aquatic Science, 46, 844-852.

Jackson, W. L. and Beschta, R. L. 1984. 'Influences of increased sand delivery on the morphology of sand and gravel channels', Water Resources Bulletin, 20(4), 527-533.

Keller, E. A. and Melhorn, W. N. 1978. 'Rhythmic spacing and origin of pools and riffles', Geological Society of America Bulletin, 89, 723-730.

Klein, R., Sonnevil, R. and Short, D. 1987. 'Effects of woody debris removal on sediment storage in a northwest California stream,' in Beschta, R. L., Blinn, T. Grant, G. E. and Swanson, F. J. (Eds), Erosion and Sedimentation in the Pacific Rim, International Association of Hydrological Sciences Publication No. 165, 403-404.

Lane, S. N. and Richards, K. S. 1997. 'Linking river channel form and process: Time, space and causality revisited', Earth Surface Processes and Landforms, 22, 249-260.

Legendre, P. and Fortin, M.-J. 1989. 'Spatial pattern and ecological analysis', Vegetation, 80, 107-138.

Leopold, L. B., Wolman, M. G. and Miller, J. P. 1964. Fluvial Processes in Geomorphology, W. H. Freeman, San Francisco, 522 pp.

Lisle, T. E. 1982. 'Effects of aggradation and degradation on riffle-pool morphology in natural gravel channels, northwestern California', Water Resources Research, 18(6), 1643-1651.

Lisle, T. E. 1986. 'Stabilization of a gravel channel by large streamside obstructions and bedrock bends, Jacoby Creek, northwestern California', Geological Society of America Bulletin, 97, 999-1011.

Lisle, T. E. 1987. Using 'Residual Depths' to monitor pool depths independently of discharge, USDA Pacific Southwest Forest and Range Experiment Station Research Note PSW-394, 4 pp.

Lisle, T. E. 1995. 'Effects of coarse woody debris and its removal on a channel affected by the 1980 eruption of Mount St. Helens, Washington', Water Resources Research, 31(7), 1797-1808.

Madej, M. A. 1996. 'Measures of stream recovery after watershed restoration', in McDonnell, J. J., Stribling, J. B. Neville, L. R. and Leopold, D. J. (Eds), Watershed Restoration Management: Physical, Chemical and Biological Considerations, American Water Resources Association, Herndon, VA, 47-56.

Madej, M. A. and Gibbs, G. 1998. Bridge Creek stream channel monitoring: Progress Report, unpublished report, US Geological Survey, Arcata, CA, 40 pp.

Madej, M. A. and Ozaki, V. 1996. 'Channel response to sediment wave propagation and movement, Redwood Creek, California, USA', Earth Surface Processes and Landforms, 21, 911-927. 
Montgomery, D. R. and Buffington, J. M. 1997. 'Channel-reach morphology in mountain drainage basins', Geological Society of America Bulletin. 109(5), 596-611.

Montgomery, D. R., Buffington, J. M., Smith, R. D., Schmidt, K. M. and Pess, G. 1995. 'Pool spacing in forest channels', Water Resources Research, 31, 1097-1105.

Murray, A. B. and Paola, C. 1996. 'A new quantitative test of geomorphic models, applied to a model of braided streams', Water Resources Research, 32(8), 2579-2587.

Nelson, J. M. 1990. 'The initial instability and finite-amplitude stability of alternate bars in straight channels', Earth Science Reviews, 29, 97-115.

O’Neill, M. P. and Abrahams, A. D. 1984. 'Objective identification of pools and riffles', Water Resources Research, 20(7), 921-926.

Ozaki, V. and Jones, C. 1998. Long-term channel stability monitoring on Redwood Creek, 1995-1997, Progress Report, unpublished report, Redwood National Park, Arcata, CA, 24 pp.

Peterson, N. P., Hendry, A. and Quinn, T. P. 1992. Assessment of cumulative effects on salmonid habitat: Some suggested parameters and target conditions, Timber Fish and Wildlife Center for Streamside Studies, University of Washington, Seattle, 75 pp.

Richards, K. S. 1976. 'The morphology of riffle-pool sequences', Earth Surface Processes, 1, 71-88.

Robert, A. 1988. 'Statistical properties of sediment bed profiles in alluvial channels', Mathematical Geology, 20(3), $205-225$.

Robert, A. and Richards, K. S. 1988. 'On the modelling of sand bedforms using the semivariogram', Earth Surface Processes and Landforms, 13, 459-473.

Robison, E. G. and Beschta, R. L. 1989. 'Coarse woody debris and channel morphology of low-gradient streams in southeast Alaska, U.S.A.', in Headwaters Hydrology, American Water Resources Association, Herndon, VA, 371-380.

Seminara, G. and Tubino, M. 1989. 'Alternate bars and meandering: Free, forced and mixed interactions', in River Meandering, American Geophysical Union Water Resources Monograph 12, Ikeda, S. and Parker, G. (Eds), 267-320.

US Forest Service. 1992. Pacific Southwest Region Fisheries Habitat Evaluation Handbook, FSH 2609.23, US Department of Agriculture Forest Service, San Francisco, CA, 300 pp. 